www.jmscr.igmpublication.org

Impact Factor 5.244

Index Copernicus Value: 83.27

ISSN (e)-2347-176x ISSN (p) 2455-0450

crossref DOI:_http://dx.doi.org/10.18535/jmscr/v4i9.27

Journal Of Medical Science And Clinical Research

IGM Publication

An official Publication of IGM Publication

\title{
A Retrospective Cytological Study of All Solitary Thyroid Nodules
}

\author{
Authors \\ Sudha Iyenger ${ }^{1}$, Shruti Gupta ${ }^{2}$, Dharmesh Chandra Sharma ${ }^{3}$, \\ Sunita Rai ${ }^{4}$, Rajesh Gaur \\ ${ }^{1}$ Associate Professor, Department of Pathology, G. R. Medical College, Gwalior INDIA \\ Email: sudha_srinivas@hotmail.com \\ ${ }^{2}$ Senior Resident, Department of Pathology, G. R. Medical College, Gwalior INDIA \\ Email: shrutigupta200288@gmail.com
}

3Associate Blood Transfusion Officer (ABTO), Incharge Blood Component, Blood Bank, Dept of

Pathology, G. R. Medical College, Gwalior. INDIA

Email:dr_dharmesh_sharma@yahoo.com

${ }^{4}$ Demonstrator, Department of Pathology, G. R. Medical College, Gwalior INDIA

Email:drsunitarai@gmail.com

${ }^{5}$ Professor \& Head of department Pathology, G. R. Medical College, Gwalior INDIA

Corresponding Author

Dr D.C. Sharma

2-B, J.A. Hospital Campus, Gwalior (MP) INDIA Pin: 474009

Mob. No.: 9826856652 and 9194251 11202, Tel. No: 91751-2630666

Email: sharmadrdharmesh@gmail.com

\begin{abstract}
Background- Fine Needle Aspiration Cytology (FNAC) is widely considered as diagnostic study of choice in assessment of thyroid lesions.

Aim- The aim of this study is to determine the various cytological patterns found in all Solitary thyroid nodules (STNs).

Setting and Design- The present study is a five retrospective study of FNAC of thyroid STNs performed in pathology department of our institute during the period of January 2009 to December 2013.

Material and Methods- The records of 185 patients who had undergone FNAC during the study period were retrieved and information about age, sex and cytological diagnosis were extracted and the corresponding original slides were reviewed. Cytological diagnosis were categorized as Neoplastic (benign/malignant), Non-neoplastic (nodular colloid goiter, colloid cyst, thyroiditis) and third category as suspicious (follicular neoplasm).
\end{abstract}

Results:- A total of 185 FNACs of STNs were done during the study period. The results of cytological diagnosis showed that 11 cases (5.94\%) had neoplastic cytological pictures (benign/malignant), 140 cases (73.37\%) had non-neoplastic pictures of STN. The cytological picture also showed 37 cases (19.69\%) were suspicious cytomorphology.

Conclusion- FNAC is a sensitive, specific and accurate initial diagnostic test for preoperative evaluation of STN and can be easily performed as an OPD procedure.

Keywords: Fine needle aspiration cytology, solitary thyroid nodule. 


\section{INTRODUCTION}

Fine needle aspiration cytology (FNAC) is a well established, low cost, simple technique which is devoid of major complications. This technique has been found to be a very useful for investigating a solitary thyroid nodule to attain a primary diagnosis. FNA in a thyroid has scored far better than thyroid scintigraphy and ultrasonography ${ }^{[1]}$; this is because FNAC gives direct morphological information of the aspirated cells. FNAC distinguishes between benign and malignant lesions quite effectively and it is the preoperative screening method of choice worldwide. This procedure also has limitations like false negative results, false positive results and a proportion of FNA results which have suspicious morphology of cells and cannot be categorized as benign or malignant ${ }^{[2]}$. Its use in recent years has resulted in significant decrease in the number of surgeries performed while increases yield of malignant lesions of patients who have undergone surgery ${ }^{[3]}$. STN that are considered for FNAC include firm palpable, solitary nodules, nodules associated with suspicious clinical or USG features, predominant nodule in MNG, recurrent cystic nodules and nodules associated with palpable lymph nodes.

\section{MATERIAL AND METHODS}

The study aims to determine the cytological pattern of thyroid lesions in addition to the utility and accuracy of FNAC as an initial diagnostic in the investigation of STN.

185 FNAs performed on patients with STN in the department of pathology, G.R. Medical college, Gwalior during the period of January 2009 And December 2013 were retrieved from the records and analyzed. All information about the age, sex and FNA diagnosis were extracted from the records and the corresponding slides were reviewed. FNAC was performed in all these patients without local anaesthesia and using aspiration and non-aspiration techniques using 22$23 \mathrm{G}$ needles. Both air dried and wet fixed (fixed in 95\% alcohol for 30 minutes) stained with May Grunwald Giemsa (MGG) and Haematoxylin and eosin (H \& E) stain respectively and examined under light microscope.

Cytology results were categorized into Neoplastic (Benign/Malignant), Non-Neoplastic (nodular colloid goiter, colloid cyst, thyroiditis) and a third category as suspicious (follicular neoplasia).

\section{RESULTS}

A total of 188 patients who underwent FNAC of STN were studied. 134 cases were females while 54 were males. Ratio of Male:female was 1:2.5 . Age of patients who presented with STNs ranged from 14 to 78 years.

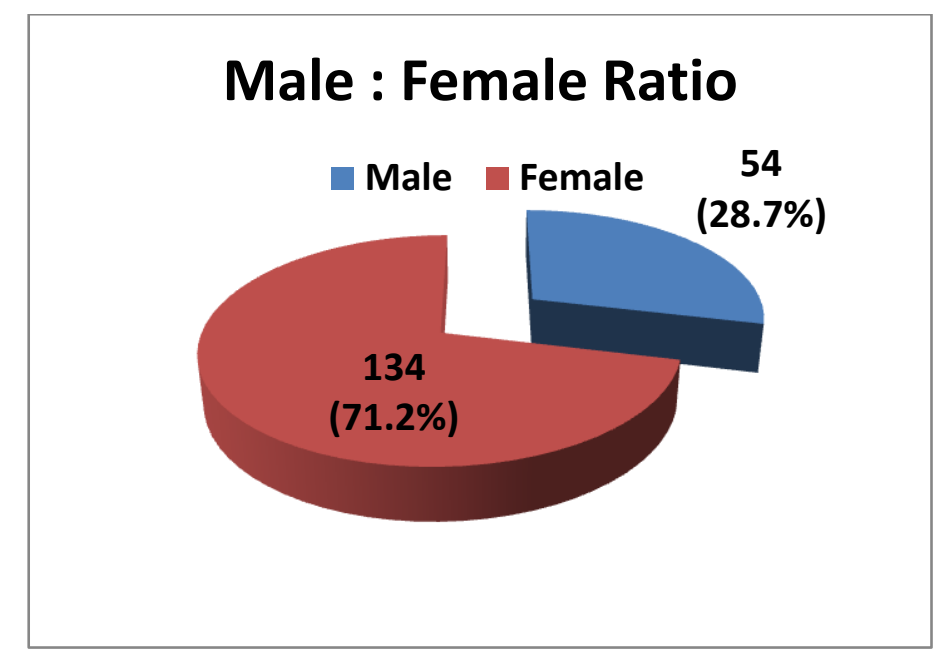

Figure 1 Male: Female Ratio of solitary thyroid nodule.

FNAC results were categorized as neoplastic (5.94\%), non-neoplastic $(74.46 \%)$, suspicious $(19.68 \%)$. The distribution of neoplastic, nonneoplastic and suspicious cases in cytology is shown in table no. 1 


\section{JMSCR Vol||04||Issue||09||Page 12473-12477||September}

Table 1: Categorization of lesions.

\begin{tabular}{|c|c|c|c|c|c|}
\hline Lesions & $\begin{array}{l}\text { No of } \\
\text { cases }\end{array}$ & Cytological diagnosis & $\begin{array}{l}\text { Number } \\
\text { of cases }\end{array}$ & \multicolumn{2}{|c|}{ Percentages } \\
\hline Neoplastic & 11 & $\begin{array}{l}\text { Benign/Malignant } \\
\text {-Oncocytoma } \\
\text {-Medullary carcinoma } \\
\text {-Anaplastic carcinoma } \\
\text {-Papillary carcinoma }\end{array}$ & $\begin{array}{l}02 \\
01 \\
02 \\
06\end{array}$ & $\begin{array}{l}1.08 \\
0.54 \\
1.08 \\
3.24\end{array}$ & 5.94 \\
\hline \multirow[t]{2}{*}{$\begin{array}{l}\text { Non- } \\
\text { neoplastic }\end{array}$} & \multirow[t]{2}{*}{140} & $\begin{array}{l}\text { Involuting thyroid nodules } \\
\text {-Nodular colloid goiter } \\
\text {-Colloid cyst }\end{array}$ & $\begin{array}{l}67 \\
53\end{array}$ & $\begin{array}{l}35.63 \\
28.19 \\
\end{array}$ & \multirow[b]{2}{*}{74.46} \\
\hline & & $\begin{array}{l}\text { Thyroiditis } \\
\text {-Hashimoto thyroidits } \\
\text {-Lymphocytic thyroiditis }\end{array}$ & $\begin{array}{l}17 \\
03\end{array}$ & $\begin{array}{l}9.04 \\
1.59\end{array}$ & \\
\hline Suspicious & 37 & Follicular neoplasm & 37 & 19.68 & 19.68 \\
\hline Total & 188 & & 188 & \multicolumn{2}{|c|}{100} \\
\hline
\end{tabular}

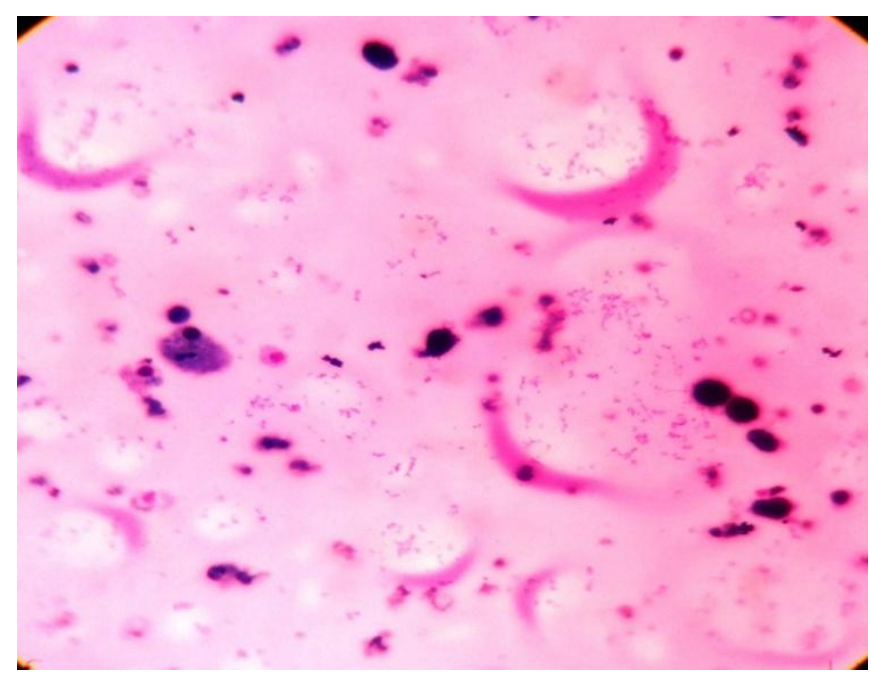

Figure 2. Bland follicular epithelial cells with occasional colloidophage in a thin colloid background-Colloid Cyst (x100 magnification)

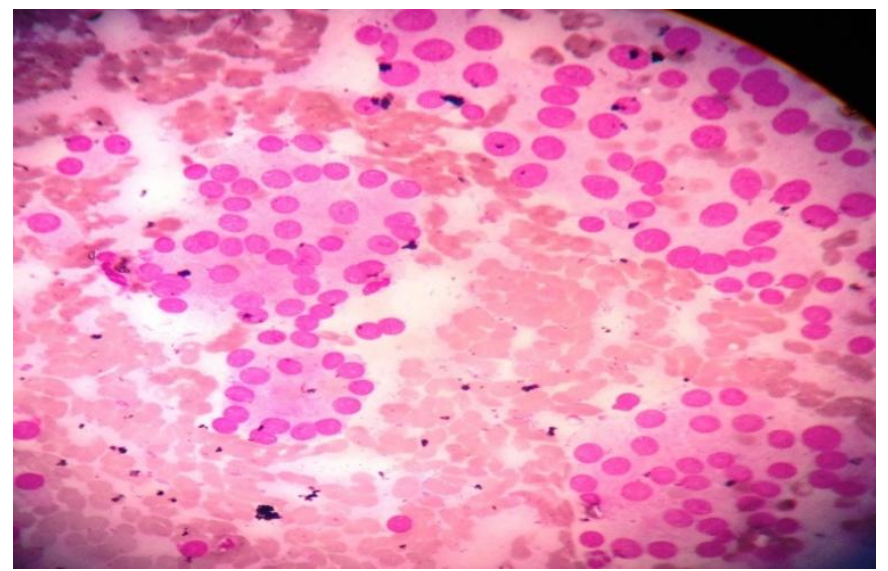

Figure 3. Follicular epithelial cells arranged in monolayered sheets and in microfolliclesFollicular Neoplasm (x100 magnification)

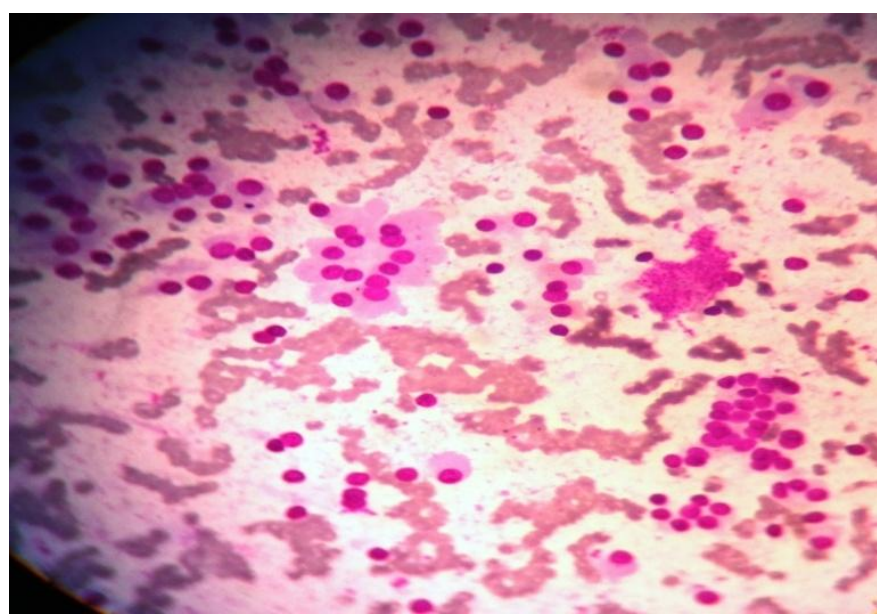

Figure 4 Bland follicular cells with oncocytes in a thin colloid background-Nodular Colloid Goiter (x100 magnification)

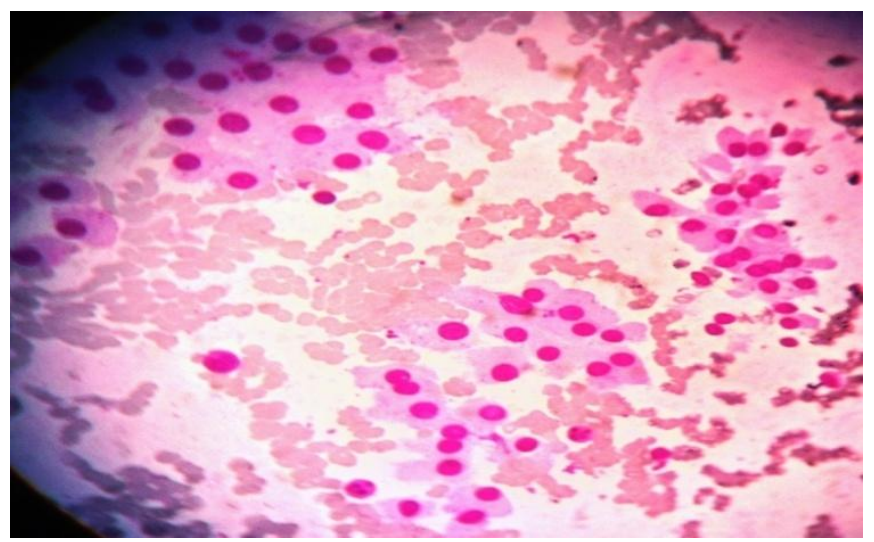

Figure 5. Oncocytes arranged in monolayered sheets and in microfollicles-Oncocytoma ( x100 magnification) 


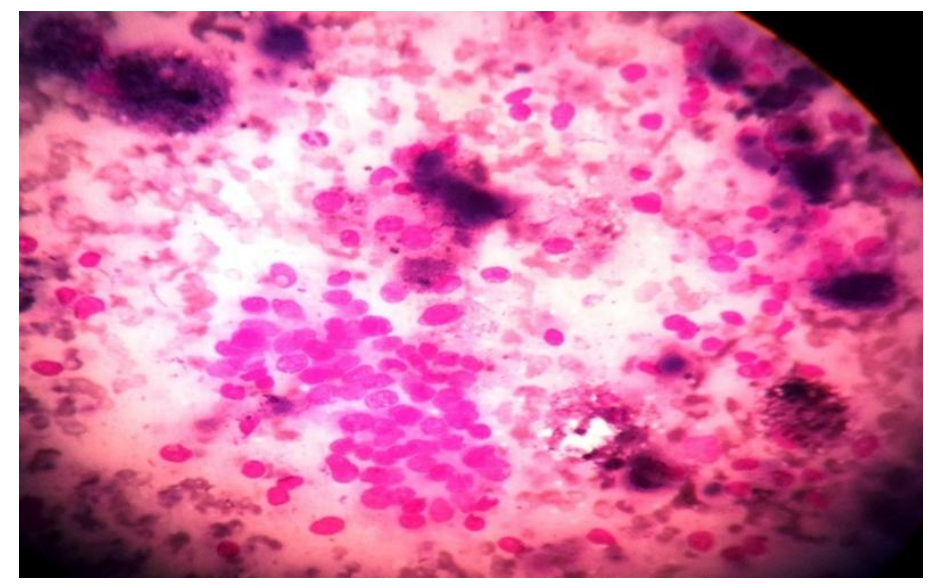

Figure 6. Cells arranged in papillae with palisading cells in the periphery with occasional cyst macrophage-Papillary Carcinoma (x100 magnification)

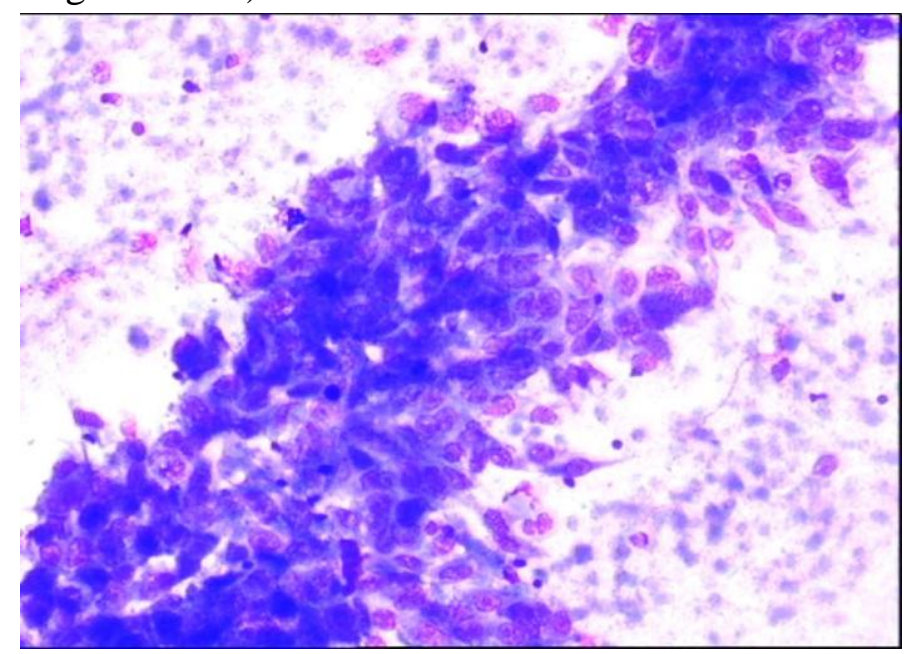

Figure 7. Multi layered sheets of highly anaplastic cells -Anaplastic Carcinoma (x100 magnification)

\section{DISCUSSION}

FNAC is regarded as the gold standard initial investigation of thyroid swellings. This technique is widely accepted as safe, simple, cost effective, quick and with a very low complication rate. We found that the accuracy of FNA analysis in STNs was $80.32 \%$ in differentiation of benign nodules from malignant nodules of thyroid gland whereas Gharib $\mathrm{H}$ et al in his study observed a differentiation of approximately $95 \%{ }^{[5]}$. FNAC has higher sensitivity for detection of malignancy compared with ultrasonography and radioisotope scans as recorded by Fonij et al ${ }^{[6]}$.

There are a group of lesions which overlap benign and malignant features, for instance, the distinction between a cellular colloid goiter and a follicular lesion may be impossible, cytological diagnosis of follicular adenoma vs carcinoma is also not possible on FNAC.

Whenever the smears were found inadequate, the patient was recalled and FNA was repeated and hence all over smears were adequate for comment. Our study shared the view of other experts in stating that FNAC is a more specific test in detecting thyroid malignancy and therefore its use as a reliable initial diagnostic test cannot be over emphasized. It reduces the need for other time consuming and expensive investigations. Our study showed that FNAC should be adapted as an initial investigation to analyze STNs in all tertiary hospitals in developing country like India as also observed by Bukhari MH et al in his study ${ }^{[7]}$.

We have categorized cytological results into Neoplastic (Benign/Malignant), Non-Neoplastic (nodular colloid goiter, colloid cyst, thyroiditis) and a third category as suspicious (follicular neoplasia).This division is very helpful to clinician in the management of patients with specific references to need of thyroid surgeries.

As most of the benign conditions can be manages medically it saves the patient's unnecessary surgery. Suspicious FNAC results are unavoidable due to overlapping cytological features particularly among hyperplastic adenomatoid nodule, follicular neoplasm and follicular variants of papillary carcinoma.

The advent of ultrasound guided FNA has improved sample acquisition from patients with small thyroid nodules which are difficult or impossible to detect on physical examination. By adopting this USG guided FNA we can reduces the percentage of inadequate samples. Borget et al did an assessment of the cost of FNA $\mathrm{C}$ as a diagnostic tool with routine ultrasound guidance in patients with STN and found that this reduced inadequate smears and hence reducing recalling of the patients as in our case and hence reduced cost and morbidity ${ }^{[8]}$.

A study by Sahaha AR showed that there were various pitfalls of FNAC on thyroid lesions. These 
were cysts (difficulties with degenerative nodules), follicular lesions (benign/malignant), Hurthle cell lesions (benign vs malignant) and lymphocytic lesions (lymphocytic thyroiditis vs lymphoma) ${ }^{[9]}$. In accordance with this study we found that there was $19.69 \%$ of suspicious lesions (benign/malignant/involuntary lesions) and $28.78 \%$ colloid cyst. The cytopathologist should be aware of potential diagnostic pitfalls and interpretational errors that can be reduced further if the aspirates are obtained from different portions of the nodule, with expert cytopathologists to perform and interpret the aspirates and with use of immunohistochemical and molecular markers.

\section{CONCLUSIONS}

The results of our study are comparable with the current published data and demonstrate that FNA cytology is a sensitive, specific and accurate initial diagnostic test for preoperative evaluation of patients with thyroid swellings in our setting as well. It is a minimally invasive, safe, easily performed OPD procedure. The clinician should be encouraged to use FNAC as the initial modality in the evaluation of thyroid lesions.

\section{REFERENCES}

1. H. Thyroid: Fine Needle Aspiration (FNA) and Cytology. Thyroid 2003;13:80-6.

2. Galera - Davidson H. Diagnostic problems in thyroid fine needle aspirations. Diag cytopathology 1997, 1:194-202.

3. Reeve D, Delbridge L, Sloan D, Crummer $P$. The impact of fine needle biopsy in surgery for single thyroid nodule. Med J Aust 1986, 145:308-311.

4. Ogilvie JB, Piatgorsky EJ, Clark $\mathrm{OH}$. Current status of fine needle aspiration for thyroid nodules. Adv surg rev 2006;40: 233-38.

5. Gharib H. Fine needle aspiration biopsy of thyroid nodules: Advantages, limitations and effects. Mayo Clin Proc 1994;79:3359.

6. Fon LJ, Deans GT, Lioe TF et al. An audit of thyroid surgery in a general surgical unit. Ann R Coll Surg Eng 1996,78:192-196.

7. Bukhari MH, Niazi S, Hanif G, Qureshi SS, Munir M, et al. An updated audit of fine needle aspiration cytology procedure of solitary thyroid nodule.Diagn Cytopathol 2008; 36:104-12.

8. Borget I, Vielh P, Leboulleux S, Allyn M, Iacobelli $S$, Schlumberger $M$, et al.Assessment of cost of fine needle aspiration cytology as a diagnostic tool in patients with thyroid nodules. Am J Clin Pathol 2008;129:763-71.

9. Shaha AR. Controversies in the management of thyroid nodule. Laryngoscope 2000; 110:183-93. 